\title{
Determinants of Brand Loyalty: A Study of the Experience-Commitment-Loyalty Constructs
}

\author{
Vishwas Maheshwari ${ }^{1}$, George Lodorfos ${ }^{1} \&$ Siril Jacobsen $^{2}$ \\ ${ }^{1}$ School of Strategy, Marketing and Communication, Faculty of Business \& Law, Leeds Beckett University, Leeds, \\ United Kingdom \\ ${ }^{2}$ Software Innovation, Oslo, Norway \\ Correspondence: Dr. Vishwas Maheshwari, School of Strategy, Marketing and Communication, Faculty of Business \\ \& Law, Leeds Beckett University, Rose Bowl Room 304, City Campus, Leeds, LS1 3HE, United Kingdom. Tel: \\ 44-11-3812-1812. E-mail: v.maheshwari@leedsbeckett.ac.uk
}

Received: October 16, 2014

doi:10.5430/ijba.v5n6p13
Accepted: November 11, 2014

Online Published: November 16, 2014

URL: http://dx.doi.org/10.5430/ijba.v5n6p13

\begin{abstract}
Marketing strategies for brands have shifted its focus on relationships and value creation that directly links to brand loyalty, is the main focus of this paper and two key factors: brand experience and brand commitment, within automotive sector, are investigated to examine relative relationships. These factors have already been established to have a connection to brand loyalty. However, as brand commitment consists of both affective and continuance commitment, it is still somewhat unclear about which of these aspects of commitment has the greatest, or most important impact on brand loyalty. Moreover, the existing research and literature surrounding the brand experience construct is extensive. However, it is not entirely clear regarding this construct's relationship to brand loyalty. While some authors claim that it affects brand loyalty directly, others have found that it is a dependent variable, which, alone does not have any immediate effect on brand loyalty. This study also investigates a connection between brand experience and brand loyalty as far as automotive sector is concerned, both with and without commitment as a mediator. As a result, continuance commitment was found to not have any considerable impact on the consumer's loyalty towards a brand, it is assumed that factors such as price and other available alternatives dos not influence this desire to maintain said relationship.
\end{abstract}

Keywords: brand loyalty, brand experience, brand commitment, branding

\section{Introduction}

The marketing field first took an interest in brand loyalty on an academic level through Copeland's work in 1923 (cited in Kabiraj and Shanmugan, 2011, p. 288), with the understanding that brand loyalty existed only at the behavioural level. At this time, brand loyalty was measured using factors such as purchase sequences, percentage of total purchases, and purchase probability (Kumar and Advani, 2005; Kabiraj and Shanmugan, 2011; Iglesias et al, 2011). This notion led to a focus on price, functionality, and quality when marketing products and services, with the expectation that customers would develop a repeated purchase pattern if these factors met the customer's criteria. However, another level of loyalty was revealed during the 1950's, as brand loyalty became an increasingly popular research area. Several researchers, such as Cunningham (1967), Day (1969) and Jacoby (1971), began to recognise that the attitudinal aspects of brand loyalty were just as important as the behavioural aspects. As it became apparent that brands often held an emotional component as well as a functional one, marketing strategies shifted to focus on relationships and value creation (Iglesias et al, 2011). Wel et al (2011) explained the two components of the phenomenon that is brand loyalty, by stating that in addition to having the intention to repurchase a brand, brand loyalists also have to hold some degree of emotional connection and/or commitment towards the brand.

It has therefore become natural for both researchers and marketers to treat brands as having both a rational and an emotional component. This has in turn contributed to creating more complex surroundings for researchers. As more research on the subject was completed, several drivers of the construct that is brand loyalty surfaced, and to this day authors are still not in complete agreement in regards to which components to apply when measuring brand loyalty. Fullerton (2003) established that commitment was of great importance to brand loyalty, and had an impact on several factors, such as values, trust, and perceived quality. Later on, Brakus et al (2009) located brand experience as another 
important driver, stating that it influenced brand loyalty indirectly through brand personality. These are just two of the measures located by authors during the last decade, and the large assortment of influencing factors greatly contributes to the academic understanding of brand loyalty. However, they can also be the cause of great confusion, as both scholars and marketers can find it difficult to determine which factors to use when measuring the level of loyalty a consumer holds towards a specific brand.

Therefore, the main focus of this paper would be on the two aforementioned factors, brand experience and brand commitment within automotive sector, which have received increasing attention from scholars during the last decade. These factors have already been established to have a connection to brand loyalty. However, as brand commitment consists of both affective and continuance commitment (Fullerton, 2003; Iglesias et al, 2011; Batra et al, 2012), it is still somewhat unclear about which of these aspects of commitment has the greatest, or most important impact on brand loyalty. Moreover, the existing research and literature surrounding the brand experience construct is extensive. However, it is not entirely clear regarding this construct's relationship to brand loyalty. While some authors claim that it affects brand loyalty directly, others have found that it is a dependent variable, which, alone does not have any immediate effect on brand loyalty. This study also aims to establish a connection between brand experience and brand loyalty as far as automotive sector is concerned, both with and without commitment as a mediator.

\section{Drivers of Brand Loyalty}

\subsection{Brand Experience}

In recent times, both academics and marketing practitioners have recognised that it is crucial to manage the customer's experience if value creation is to be achieved (Berry et al., 2002; Iglesias et al., 2010). As such, marketing is shifting its focus from quality to experience (Klaus and Maklan, 2013), and it is therefore becoming increasingly important to be able to define and develop brand experience if organisations hope to gain a competitive advantage in the market (Ismail et al., 2011). As the concept of brand experience was introduced, it quickly received recognition by several scholars, and thereafter, the concept became an equivalent to value creation (Carù and Cova, 2003; Ponsonby-McCabe and Boyle, 2006; Iglesias et al, 2011). However, even though most agree that brand experience entails value creation, and holds great importance to the marketing field, an agreement of a common definition is not yet available. Moreover, brand experience has evolved into a generic concept that spans across several experience categories such as service experience, product experience, customer experience, etc. (Zarantonello and Schmitt, 2010). Consequently, brand experience now consists of several dimensions, and regrettably, an agreement is yet to be reached as to which dimensions are more appropriate. As such, the complexity surrounding brand experience increases, and a review of the present dimensions is therefore in order. In context, Brakus et al (2009) located the four dimensions sensorial, affective, behavioural and intellectual, to be the most important aspects of brand experience. These dimensions are supported by scholars such as Ismail et al (2011), Zarantonello and Schmitt (2010), Iglesias et al (2011), and Hultén (2011). This, in addition to the fact that the four dimensions were tested across over 30 different brands in various industries, means that the dimensions are considered to be both valid and reliable, and directly applicable to the automotive industry, as this industry actually took part in the research. The authors will therefore apply these four dimensions of brand experience when moving forward with the primary research later on.

\subsection{Brand Commitment}

Brand commitment is an attitudinal concept that has received increasing interest within the marketing field during the last decades, and has been established as an important factor regarding relationship marketing and consumer behaviour (Morgan and Hunt, 1994; Sargeant and Lee, 2004; Sung and Campbell, 2009). In fact, Bozzo et al (2003) found that a committed consumer would be willing to make some sort of sacrifice in order to make the relationship work, which further stresses the importance of brand commitment in marketing. As such, brand commitment can be defined as "an enduring desire to maintain a valued relationship" (Berry and Parasuraman, 1991, p. 316). The value and importance of brand commitment is clearly displayed in the aforementioned definition, as it illustrates that a highly committed consumer will work harder to maintain a relationship with a brand than a consumer that holds no, or low commitment to a brand. However, researchers in the marketing field have been more concerned with commitment in a organisational context, where organisational and employee commitment is in focus, rather than consumer commitment towards the actual brand (Allen and Meyer, 1990; Burmann and Zeplin, 2005; Burmann et al., 2009; Gong et al., 2009; Priyadarshi, 2011). Nevertheless, consumer brand commitment is still an important construct, and it is crucial that marketers are aware of the importance of building and maintaining consumer relationships, as this is closely linked with commitment. 
Additionally, brand commitment is known to have several components. The most accepted components in the marketing field are affective and continuance commitment, stemming from a three-component model located in the organisational psychology field by Allen and Meyer (1990). Their research originally revealed commitment to consist of affective, continuance, and normative commitment. However, this three-component model is open to criticism, as there is a shortage of existing literature surrounding normative commitment, in addition to the fact that their research revealed an "overlap between affective and normative commitment" (Allen and Meyer, 1990, p. 13), making the two components difficult to separate. This could explain why marketing scholars generally tend to focus on the first two components, and this research paper will therefore act in accordance with the marketing literature in determining that brand commitment consists of affective and continuance commitment.

\subsubsection{Affective Commitment}

According to Amine (1998), affective commitment reflects the extent to which a consumer wants to maintain a relationship with a brand based on their emotional attachment to the brand. This phenomenon includes the extent to which the consumer identifies with the brand, and is the core of the consumer-brand relationship (Louis and Lombart, 2010). Furthermore, Bansal et al., (2004) explained that affective commitment is centred around the consumer's emotional attachments to the brand, their identification with the brand, and their involvement with the brand. These three factors will evidently lead to a desire to maintain the brand relationship

As the focus of marketing has shifted from deals to relationships, it is natural that affective commitment, being an emotional component, has received more attention from researchers than continuance commitment has in recent years. However, scholars have rarely focused on affective commitment as an independent factor. Rather, the literature points to affective commitment as having a mediating role. Bansal et al., (2004) argued that it acts as a mediator between switching intentions, satisfaction and trust, while others have found that it mediates experience and loyalty (Iglesias et al., 2011), and experience, satisfaction and loyalty (Fullerton, 2005). However, the exact mediating role and effect of affective commitment has not yet been agreed upon by researchers.

\subsubsection{Continuance Commitment}

Continuance commitment, also known as cost-induced commitment (Ritzer and Trice, 1969), calculative commitment (Srivastava and Owens, 2010) and economic commitment (Evanschitzky and Wunderlic, 2006), differs from affective commitment in several ways. There are numerous definitions on the matter, however, most researchers tend to agree that continuance commitment occurs when the benefits of staying trumps the costs of leaving a relationship (Bansal et al, 2004). While affective commitment is based on the consumer's emotions, continuance commitment is a more rational component, where the cost of leaving a relationship, and a lack of other alternatives creates a rationale for the consumer to be committed to the brand (Meyer and Herscovitch, 2001; Bansal et al, 2004). Fullerton (2003) further explained that continuance commitment occurs when specific actions are taken that will force the relationship over a period of time, such as contracts, service agreements, investments and pledges. These types of relationships can often create feelings of entrapment or dependence, which both are fundamental in the continuance commitment construct. While consumers who experiences affective commitment will resist any attitudinal changes, and will always behave favourably towards the brand, this is not necessarily the case for consumers who stays in a brand relationship merely because they feel like they "have to" (Sung and Campbell, 2009). However, researchers does not yet agree on the extent to which continuance commitment can enhance or reduce brand loyalty. Consequently, there are limitations to the literature regarding the effects of continuance commitment.

Evanschitzky et al (2006) argued that, seeing as buyers and sellers in the consumer market often have several alternatives available to them, as well as low switching costs between products, affective commitment generally has a greater impact on brand loyalty than continuance commitment does. This notion was later supported by Srivastava and Owens (2010), who stated that brand commitment was different from calculative, or continuance commitment, as brand commitment was influenced by the individual's trust and attitudes towards the brand. Sung and Campbell (2009) on the other hand, found that consumers experience positive feelings of commitment when few or poor-quality alternatives are present, or when expected losses following a termination of the relationship are high. In addition to these two contradicting views, some researchers have argued that affective and continuance commitment are not mutually exclusive. In fact, Fournier et al (1998) and Grayson and Ambler (1999) recognised that both brand loyalty and consumer behaviour in general, could be influenced by both positive feelings of affect as well as feelings of continuance. However, there is not sufficient literature to support either views (Fullerton, 2005). Further research on continuance commitment's effect of brand loyalty contra the effects of affective commitment is therefore in order. 


\subsection{Brand Loyalty}

The concept of brand loyalty has been recognised as an important construct in the marketing literature for at least four decades (Howard and Sheth, 1969), and most researchers agree that brand loyalty can create firm benefits such as reduced marketing costs (Chaudhuri and Holbrook, 2001), positive word of mouth (Sutikno, 2011), business profitability (Kabiraj and Shanmugan, 2011), increased market share (Gounaris and Stathakopoulos, 2004) and a competitive advantage in the market (Iglesias et al, 2011). These benefits clearly reveals the positive impact brand loyalty can have on a firm, and as such, Khan and Mahmood (2012, p. 33) suggested a definition that reflected these benefits in an efficient manner, by stating that "brand loyalty can be defined as the customer's unconditional commitment and a strong relationship with the brand, which is not likely to be affected under normal circumstances".

In spite of the fact that there is a common agreement between researchers regarding the benefits that follows brand loyalty, marketing practitioners and scholars have yet to agree on a definition of the concept. However, the literature still reveals some common denominators, as most researchers agrees that brand loyalty can be either true or spurious (Day, 1996; Lin, 2010; Iglesias et al, 2011; Kumar and Advani, 2005). While spurious loyalty is driven by situational circumstances such as price and convenience (Iglesias et al, 2011), true brand loyalty holds some indicator of previous psychological and affective attachment to the brand (Lin, 2010). In addition to true and spurious loyalty, other scholars have suggested that brand loyalty holds several other dimensions. However, in recent marketing literature, true and spurious brand loyalty are still the most recognised dimensions, and as such, this research paper will focus on the impact brand experience and commitment has on true brand loyalty when moving forward with the research.

The notion of brand loyalty as a two-component structure is still considered as being highly appropriate among researchers. However, recent studies has viewed brand loyalty as a multi-dimensional construct, and as such, it is in need of multivariate measurements (Punniyamoorthy and Raj, 2011). This new prospect creates room for several measurements and interpretations, and as of this moment researchers are not yet in agreement regarding which measurements to use. While some researchers has used involvement (Traylor, 1983), brand trust (Garbarino and Johnson, 1999) and satisfaction (Wang et al, 2004), other researchers have revealed an increased interest in commitment and experience (Fullerton, 2003; Brakus et al., 2009; Iglesias et al., 2011). However, these are more recent constructs and therefore under-researched (Iglesias et al., 2011), especially regarding commitment as a mediating construct between experience and loyalty, as it is perceived in this research paper.

The literature has revealed that there was a lack of agreement among scholars both concerning brand loyalty definitions and measures. This disagreement, especially regarding the lack of a common brand loyalty measure, can be the cause of great confusion, and evidently, invalid data. However, Newman and Werbel (1973; cited in Kabiraj and Shanmugan, 2011, p. 289) argued that in order for brand loyalty measures to be valuable for marketers, the measures should contain the consumer's unwillingness to switch brands. Presuming that this statement is correct, brand commitment is a valid brand loyalty measure. As reflected in the literature, brand commitment is conceptualised as the consumer's desire to maintain a relationship with the brand, which has a direct influence on their reluctance to switch brands. Based on the literature, the authors therefore expect to find that both affective and continuance commitment has an impact on brand loyalty. Based on Newman and Werbel's statement, it is also presumed that brand experience is a valid measure of brand loyalty, as it is more likely that consumer's who encounters a superior brand experience will prefer this brand in the future (Brakus et al., 2009), which will evidently cause a reluctance to switch brands. The literature also revealed that brand experience can be viewed as having both a direct and indirect impact on loyalty, as some authors has named brand commitment as a mediator between experience and loyalty. However, there is not sufficient evidence in the literature to suggest which of these views are correct, as brand experience is still an under-researched concept, and commitment as a mediator of the relationship has yet to be validated. The authors, therefore, expects to validate this relationship between experience and loyalty, both with and without commitment as a mediator.

\section{Methodology}

As the automotive industry holds a high level of brand involvement for consumers when they are making a purchase decision (Rosenbaum-Elliot et al., 2011), this industry was considered to be highly suitable as the field of study considering the purpose of the research. This study therefore used car owners between the ages 40-70 in Oslo, Norway, as the target population from which research data was collected. Moreover, as automobiles are high-priced products with a long life cycle, it was more likely that consumers over the age of forty would have owned several cars, and as such, they have had the opportunity to create preferences and loyalty towards a specific car brand. In 
order to make sure that the sample was in fact representative for the population, quota sampling was used. As this research did not contain many attribute variables, the quotas was only determined based on the population's division of gender and age. According to Statistics Norway (2012), the population in Oslo between the ages of 40-80 was as follows:

Table 1. Division of gender and age in Oslo

\begin{tabular}{llll}
\hline Age & $\mathbf{4 0 - 5 4}$ & $\mathbf{5 5 - 6 6}$ & $\mathbf{6 7 - 7 9}$ \\
\hline Male & 63292 & 35039 & 17890 \\
Female & 57845 & 35711 & 21657 \\
\hline
\end{tabular}

(Adapted from Statistics Norway, 2012)

The sample size consisted of a 0,1 per cent quota for each group, which provided the survey with a total of 232 respondents. Several authors researching brand loyalty measures has recognised that this is a sufficient sample size (Iglesias et al, 2011; Sahin et al, 2011; Loureiro et al, 2012), and as there was no way of calculating the appropriate sample size when a non-probability sampling technique was being used (Saunders et al., 2012), this was considered to be a suitable size. As such, these were the quotas being used in the research in order to make them representative for the population.

Table 2. Quota sampling

\begin{tabular}{llll}
\hline Age & $\mathbf{4 0 - 5 4}$ & $\mathbf{5 5 - 6 6}$ & $\mathbf{6 7 - 7 9}$ \\
\hline Male & 63 & 35 & 18 \\
Female & 58 & 36 & 22 \\
\hline
\end{tabular}

While the attribute variables was formulated through one numeric question (age) and two category questions (gender and car brand), the rest of the questionnaire consisted of rating questions in the form of a five-point likert scale, which according to Saunders et al. (2012) is useful when collection opinion data. Using the likert scale, respondents were asked to rate the extent to which the statements in the questionnaire described his or her experiences, commitment and loyalty related to the car brand they were in possession of.

As found in the literature review, brand experience consists of four dimensions; sensorial, affective, behavioural and intellectual. These four experience dimensions were measured using a twelve item scale introduced by Brakus et al. (2009), where each dimension held three items. Moreover, loyalty was measured by adopting five items used by Yoo and Donthu (2001) and Brakus et al. (2009). These five items covered both attitudinal and behavioural loyalty. Finally, brand commitment was measured using a three item scale by Evanschitzky et al. (2006), which measured affective commitment, and a four item scale adopted from Allen and Meyer (1990), who originally introduced an eight item scale for measuring organisational continuance commitment. The eight item scale was modified in order to make it a valid measure for brand continuance commitment, leaving it with four modified items.

\section{Findings \& Discussion}

On an average, respondents were of 56 years with a standard deviation of 9,5 years. There were 118 males and 114 female respondents in total. All data were processed using the statistical analysis program SAS jmp.

The purpose of the data analysis was to establish relationships between different variables, both independently and dependently.

In order to move forward with establishing relationships between the different variables in the research, the researchers used the principal components method by applying Confirmatory Factor Analysis (CFA) in SAS jmp to capture as much of the variance in the original variables as possible, while using a minimum of components. The numbers extracted from the CFA analysis enabled us to calculate the average variance extracted for each main variable which helped us to narrow down what used to be 24 items to four items as shown in table 3 below, making the rest of the analysis much more comprehensible. The four items left that were to be analysed further now consisted of the main characteristics of brand experience, continuance commitment, affective commitment, and brand loyalty. 
Table 3. Rotated factor loadings

\begin{tabular}{|c|c|c|c|c|c|c|c|}
\hline & $\begin{array}{l}\text { BRAND } \\
\text { EXPERIE } \\
\text { NCE } 1 \\
\end{array}$ & $\begin{array}{l}\text { BRAND } \\
\text { EXPERIE } \\
\text { NCE } 2 \\
\end{array}$ & $\begin{array}{l}\text { BRAND } \\
\text { EXPERIE } \\
\text { NCE } 3 \\
\end{array}$ & $\begin{array}{l}\text { BRAND } \\
\text { EXPERIE } \\
\text { NCE } 4 \\
\end{array}$ & $\begin{array}{l}\text { BRAND } \\
\text { LOYALTY }\end{array}$ & $\begin{array}{l}\text { CONTINUANCE } \\
\text { COMMITMENT }\end{array}$ & $\begin{array}{l}\text { AFFECTIVE } \\
\text { COMMITMENT }\end{array}$ \\
\hline $\begin{array}{l}\text { ITEM } \\
1\end{array}$ & 0,95 & - & - & - & - & - & - \\
\hline $\begin{array}{l}\text { ITEM } \\
2\end{array}$ & 0,95 & - & - & - & - & - & - \\
\hline $\begin{array}{l}\text { ITEM } \\
3\end{array}$ & 0,87 & - & - & - & - & - & - \\
\hline $\begin{array}{l}\text { ITEM } \\
4\end{array}$ & - & 0,91 & - & - & - & - & - \\
\hline $\begin{array}{l}\text { ITEM } \\
5\end{array}$ & - & 0,90 & - & - & - & - & - \\
\hline $\begin{array}{l}\text { ITEM } \\
6\end{array}$ & - & 0,91 & - & - & - & - & - \\
\hline $\begin{array}{l}\text { ITEM } \\
7\end{array}$ & - & - & 0,90 & - & - & - & - \\
\hline $\begin{array}{l}\text { ITEM } \\
8\end{array}$ & - & - & 0,89 & - & - & - & - \\
\hline $\begin{array}{l}\text { ITEM } \\
9\end{array}$ & - & - & 0,63 & - & - & - & - \\
\hline $\begin{array}{l}\text { ITEM } \\
10\end{array}$ & - & - & - & 0,93 & - & - & - \\
\hline $\begin{array}{l}\text { ITEM } \\
11\end{array}$ & - & - & - & 0,94 & - & - & - \\
\hline $\begin{array}{l}\text { ITEM } \\
12\end{array}$ & - & - & - & 0,88 & - & - & - \\
\hline $\begin{array}{l}\text { ITEM } \\
13\end{array}$ & - & - & - & - & 0,89 & - & - \\
\hline $\begin{array}{l}\text { ITEM } \\
14\end{array}$ & - & - & - & - & 0,87 & - & - \\
\hline $\begin{array}{l}\text { ITEM } \\
15\end{array}$ & - & - & - & - & 0,91 & - & - \\
\hline $\begin{array}{l}\text { ITEM } \\
16\end{array}$ & - & - & - & - & 0,87 & - & - \\
\hline $\begin{array}{l}\text { ITEM } \\
17\end{array}$ & - & - & - & - & 0,74 & - & - \\
\hline $\begin{array}{l}\text { ITEM } \\
18\end{array}$ & - & - & - & - & - & 0,88 & - \\
\hline $\begin{array}{l}\text { ITEM } \\
19\end{array}$ & - & - & - & - & - & 0,83 & - \\
\hline $\begin{array}{l}\text { ITEM } \\
20\end{array}$ & - & - & - & - & - & 0,72 & - \\
\hline $\begin{array}{l}\text { ITEM } \\
21\end{array}$ & - & - & - & - & - & 0,29 & - \\
\hline $\begin{array}{l}\text { ITEM } \\
22\end{array}$ & - & - & - & - & - & - & 0,73 \\
\hline $\begin{array}{l}\text { ITEM } \\
23\end{array}$ & - & - & - & - & - & - & 0,90 \\
\hline $\begin{array}{l}\text { ITEM } \\
24\end{array}$ & - & - & - & - & - & - & 0,88 \\
\hline
\end{tabular}


Furthermore, chi-square tests were run to establish connections between different variables after establishing below listed hypotheses as a result of literature review discussion at the beginning of the paper. Five hypotheses could be derived from the literature review and the research objectives:

$\mathrm{H}_{0=}$ There is not a direct link between affective commitment and brand loyalty

$\mathrm{H}_{1}=$ There is a direct link between affective commitment and brand loyalty

$\mathrm{H}_{0}=$ There is not a direct link between continuance commitment and brand loyalty

$\mathrm{H}_{1}=$ There is a direct link between continuance commitment and brand loyalty

$\mathrm{H}_{0=}$ There is not a direct link between brand experience and brand loyalty

$\mathrm{H}_{1}=$ There is a direct link between brand experience and brand loyalty

$\mathrm{H}_{0}=$ Affective commitment does not act as a mediator between brand experience and brand loyalty

$\mathrm{H}_{1}=$ Affective commitment does act as a mediator between brand experience and brand loyalty

$\mathrm{H}_{0}=$ Continuance commitment does not act as a mediator between brand experience and brand loyalty

$\mathrm{H}_{1}=$ Continuance commitment does act as a mediator between brand experience and commitment

The chi-square test explored each of these hypotheses in turn, using a 5\% significance. Table 4 reveals the significance level between each relationship

Table 4. Chi-square test

\begin{tabular}{ll}
\hline Brand experience by brand loyalty & $\mathbf{P}<, 0001^{*}$ \\
Experience by affective commitment & $\mathbf{P}<, 0001^{*}$ \\
Experience by continuance commitment & $\mathbf{0 , 6 5 4 4}$ \\
Continuance commitment by brand loyalty & $\mathbf{0 , 4 2 8 6}$ \\
Affective commitment by brand loyalty & $\mathbf{P}<, 0001^{*}$ \\
\hline
\end{tabular}

As revealed in above Table 4, all null hypotheses were rejected, except from the ones regarding continuance commitment, suggesting that there was not a significant relationship between continuance commitment and brand loyalty, neither directly nor indirectly as a mediator. As continuance commitment was revealed as a non-significant determinant for the brand loyalty construct, the research paper has confirmed what had been assumed by several researchers in the literature review. It was still a significant finding however, as there was little research actually confirming the theory that continuance commitment did not affect brand loyalty, particularly in the experience-commitment-loyalty construct. Moreover, the authors found, with a $99 \%$ certainty, that brand experience had a significant influence on brand loyalty, both as a stand alone and mediated factor. Similarly, there was a $99 \%$ certainty that affective commitment influenced brand loyalty both individually and as a mediator between experience and loyalty. The findings above were not considered to be completely reliable however, as $20 \%$ of the cells had an expected count of less than 5 , which indicated that the chi-square test could be suspected as unreliable. According to Gripsrud et al (2010), when this occurs, it is prudent to perform a pearson correlation test as well, in order to confirm that the data can in fact be relied upon. Therefore, Pearson's correlation test was performed as outlined in the table 5 below:

Table 5. Pearson correlation

\begin{tabular}{lll}
\hline & Correlation & Significant probability \\
\hline Brand experience by brand loyalty & 0,6753 & $<, 0001^{*}$ \\
Experience by affective commitment & 0,6316 & $<, 0001^{*}$ \\
Experience by continuance commitment & $-0,0494$ & 0,4539 \\
Continuance commitment by brand loyalty & $-0,0881$ & 0,1813 \\
Affective commitment by brand loyalty & 0,6761 & $<, 0001^{*}$ \\
\hline
\end{tabular}


As seen in Table 5, the three null hypotheses that were rejected in the chi-square test were also rejected in this Pearson correlation test, with a $\mathrm{p}<, 0001$ probability, meaning that there was in fact a statistically significant correlation between brand experience and brand loyalty, affective commitment and brand loyalty, and affective commitment as a mediator between brand experience and brand loyalty. Moreover, the three relationships all held a correlation between 0,6 and 0,7 , meaning that the correlations were all significantly different from null considering the $5 \%$ scale. In addition, the probability values $\mathrm{p}<, 0001$ confirmed that there was in fact a $99 \%$ probability that brand experience, affective commitment and brand loyalty was connected. Again, the null hypotheses regarding continuance commitment was not rejected, and as such, continuance commitment was confirmed as a variable that had no considerable influence on brand loyalty, neither as an individual or a mediating factor. As the findings from the chi-square test was proven to be reliable, the data suggested a model somewhat similar to that of Iglesias et al (2011). There were however, differences between this model suggested by Iglesias et al (2011) and the findings in this research. In fact, the research project undertaken by the aforementioned authors did not establish a direct link between brand experience and brand loyalty. Instead, they found that brand experience acted as an indirect variable, only affecting brand loyalty when mediated by affective commitment. As discussed earlier in the chapter, this research revealed brand experience as both a dependent and independent variable, and as such, the structural model of these research findings would look somewhat different (see Figure 1).

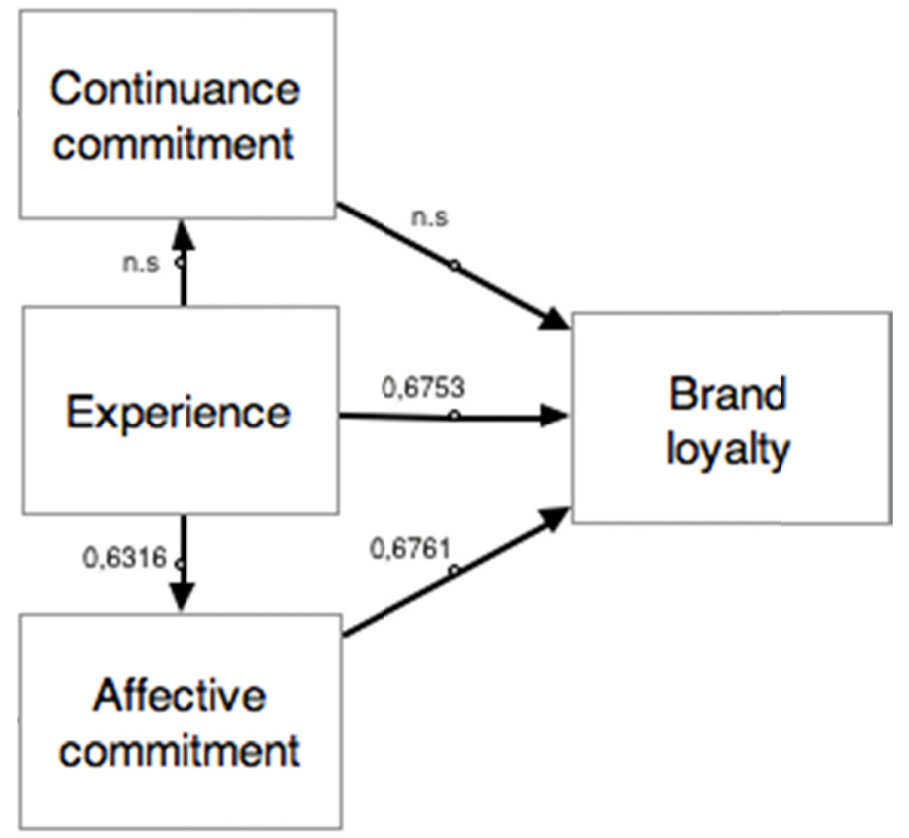

Figure 1. Structural model

The structural model of the research findings in figure 1 illustrates how the data analysis revealed both direct and indirect relationships between experience, affective commitment, and loyalty, and to which degree the relationships were significant (values extracted from Table 5). It also shows how hypotheses 2 and 5 were kept, by establishing that these relationships were not significant.

\section{Conclusion and Implications}

Based on the findings discussed above, assumptions can be drawn related to the mind-set of the loyal consumer. As stated in the literature review, loyal consumers are emotional creatures which are highly driven by their desire to maintain a relationship with the brand they feel an emotional connection with. As continuance commitment was found to not have any considerable impact on the consumer's loyalty towards a brand, it is assumed that factors such as price and other available alternatives dos not influence this desire to maintain said relationship. As such, this research does not support the beliefs of Sung and Campbell (2009) when they stated that positive feelings of commitment towards a brand could occur when the consumer was faced with poor-quality alternatives or when the losses related to terminating the relationship was high. Consequently, even though feelings related to continuance commitment engages the consumer in a brand relationship, these feelings are not enough to develop feelings of 
loyalty in the consumer's mind. organisations should therefore rather focus on creating positive brand experiences for the consumer, and establishing an emotional connection between the consumer and the brand, as this emotional connection is vital in establishing affective commitment, which was found to be an important driver of brand loyalty.

Moreover, while this research has established that continuance commitment does not lead to brand loyalty, it has not established whether it can in fact have an opposite effect. Marketing managers could benefit from such research, as it would help establish whether continuance commitment could in fact damage the consumer's loyalty towards the brand. As such, it would be useful for further research to explore the extent to which continuance commitment can have a negative impact on brand loyalty.

\section{References}

Allen, N., \& Meyer, J. (1990). The Measurement and Antecedents of Affective, Continuance and Normative Commitment to the Organization. Journal of Occupational Psychology, 63, 1-18. http://dx.doi.org/10.1037/0021-9010.75.6.710

Amine, A. (1998). Consumers' true brand loyalty: the central role of commitment. Journal of Strategic Marketing, 6(4), 305-319. http://dx.doi.org/10.1080/096525498346577

Bansal, H.S., Irving, P.G., \& Taylor, S.F. (2004). A three-component model of customer commitment to service providers. Journal of the Academy of Marketing Science, 32(3), 234-250. http://dx.doi.org/10.1177/0092070304263332

Batra, R., Ahuvia, A., \& Bagozzi, R.P. (2012). Brand love. Journal of Marketing, 76(2), 1-16. http://dx.doi.org/10.1509/jm.09.0339

Berry, L.L., Carbone, L.P., \& Haeckel, S.H. (2002). Managing the total customer experience. Sloan Management Review, 43(Spring), 85-89.

Berry, L.L., \& Parasuraman, A. (1991). Marketing Services. New York, The Free Press.

Bozzo, C., Merunka, D., \& Moulins, J.L. (2003). Fide' lite' et comportement d'achat: ne pas se fier aux apparences. Decisions Marketing, 32(4), 9-17. http://www.jstor.org/stable/40592929

Brakus, J.J., Schmitt, B.H., \& Zarantonello, L. (2009, May). Brand experience: What is it? How is it measured? Does it affect loyalty? Journal of Marketing, 73, 52-68. http://dx.doi.org/10.1509/jmkg.73.3.52

Burmann, C., \& Zeplin, S. (2005). Building brand commitment: A behavioural approach to internal brand management. Journal of Brand Management, 12(4), 279-300. http://dx.doi.org/10.1057/palgrave.bm.2540223

Burmann, C., Zeplin, S., \& Riley, N. (2009). Key determinants of internal brand management success: An exploratory empirical analysis. Journal of Brand Management, 16(4), 264-284. http://dx.doi.org/10.1057/bm.2008.6

Carù, A., \& Cova, B. (2003). Revisiting consumption experience: A more humble but complete view of the concept. Marketing Theory, 3(2), 267-286. http://dx.doi.org/10.1177/14705931030032004

Chaudhuri, A., \& Holbrook, M.B. (2001). The Chain of Effects From Brand Trust and Brand Affects to Brand Performance: The Role of Brand Loyalty. Journal of Marketing, 65(2), 81-93. http://dx.doi.org/10.1509/jmkg.65.2.81.18255

Copeland, M.T. (1923). Relation of consumers' buying habits to marketing methods. Harvard Business Review, 1(2), 282-289. Cited in Kabiraj, S., \& Shanmugan, J. (2011). Development of a Conceptual Framework for Brand Loyalty: A Euro-Mediterranean Perspective. Journal of Brand Management, 18(4/5), 285-299. http://dx.doi.org/10.1057/bm.2010.42

Cunningham, S.M. (1966). Brand loyalty-what, where, how much? Harvard Business Review, 34, 116-28.

Cunningham, S.M. (1967). Perceived risk and brand loyalty. In Cox, D. (Ed.), Risk Taking and Information Handling in Consumer Behaviour (pp. 132-138). Boston, Harvard University Press.

Day, G.S. (1969). A two-dimensional concept to brand loyalty. Journal of Advertising Research, 9, 29-35.

Evanschitzky, H., Iyer, G.R., Plassmann, H., Niessing, J., \& Meffert, H. (2006). The relative strength of affective commitment in securing loyalty in service relationships. Journal of Business Research, 59(12), 1207-1213. http://dx.doi.org/10.1016/j.jbusres.2006.08.005

Evanschitzky, H., \& Wunderlic, M. (2006). An examination of moderator effects in the four-stage loyalty model. 
Journal of Services Research, 8(4), 330-345. http://dx.doi.org/10.1177/1094670506286325

Fournier, S. (1998). Consumers and their brands: developing relationship theory in consumer research. Journal of Consumer Research, 24(4), 343-373. http://dx.doi.org/10.1086/209515

Fullerton, G. (2003). When does commitment lead to loyalty? Journal of Service Research, 5(4), 333-344. http://dx.doi.org/10.1177/1094670503005004005

Fullerton, G. (2005). The Impact of Brand Commitment on Loyalty to Retail Service Brands. Canadian Journal of Administrative Sciences, 22(2), 97-110.

Garbarino, E., \& Johnson, S. M. (1999, April). The Different Roles of Satisfaction, Trust, and Commitment In $\begin{array}{lllll}\text { Customer Relationships. } & \text { Journal }\end{array}$ http://dx.doi.org/10.1111/j.1936-4490.2005.tb00712.x

Gong, Y., Law, K.S., Chang, S., \& Xin, K.R. (2009). Human Resources Management and Firm Performance: The Differential Role of Managerial Affective and Continuance Commitment. Journal of Applied Psychology, 94(1), 263-275. http://dx.doi.org/10.1037/a0013116

Gounaris, S., \& Stathakopoulos, V. (2004). Antecedents and consequences of brand loyalty: An empirical study. Journal of Brand Management, 11(4), 283-306. http://dx.doi.org/10.1057/palgrave.bm.2540174

Grayson, K., and Ambler, T. (1999, February). The Dark Side of Long-Term Relationships in Marketing Services. Journal of Marketing Research, 36, 132-141.

Howard, J., \& Seth, J. (1969). The Theory of Buyer Behavior. New York, John Wiley \& Sons.

Hultén, B. (2011). Sensory marketing: the multi-sensory brand-experience concept. European Business Review, 23(3), 256-273.

Iglesias, O., Singh, J.J., \& Batista-Foguet, J.M. (2011). The role of brand experience and affective commitment in determining brand loyalty. Brand Management, 18(8), 570-582. http://dx.doi.org/10.1057/bm.2010.58

Ismail, A.R., Melewar, T.C., Lim, L., \& Woodside, A. (2011). Customer Experiences With Brands: Literature Review and Research Directions. The Marketing Review, 11(3) 205-225. http://dx.doi.org/10.1362/146934711X589435

Jacoby, J. (1971, June). A model of multi-brand loyalty. Journal of Advertising Research, 11, 25-31.

Kabiraj, S., \& Shanmugan, J. (2011). Development of a Conceptual Framework for Brand Loyalty: A Euro-Mediterranean Perspective. Journal of Brand Management, 18(4/5), 285-299. http://dx.doi.org/10.1057/bm.2010.42

Khan, M.A., \& Mahmood, Z. (2012, January). Impact of Brand Loyalty Factors on Brand Equity. International Journal of Academic Research, 4(1), 33-37.

Klaus, P., \& Maklan, S. (2013). Towards a Better Measure of Customer Experience. International Journal of Market Research, 55(2), 227-246. http://dx.doi.org/10.2501/IJMR-2013-021

Kumar, S.R., \& Advani, J., Y. (2005). Factors affecting brand loyalty: A study in an emerging market on fast moving consumer goods. Journal of Customer Behaviour, 4(2), 251-275. http://dx.doi.org/10.1362/1475392054797223

Lin, L. (2010). The relationship of consumer personality trait, brand personality and brand loyalty: an empirical study of toys and video games buyers. Journal of Product and Brand Management, 19(1), 4-17.

Louis, D., \& Lambart, C. (2010). Impact of brand personality on three major relational consequences (trust, attachment, and commitment to the brand). Journal of Product and Brand Management, 19(2), 114-130.

Meyer, J.P., \& Herscovitch, L. (2001). Commitment in the Workplace: Toward a General Model. Human Resource Management Review, 11(3), 299-326. http://dx.doi.org/10.1016/S1053-4822(00)00053-X

Morgan, R.M., \& Hunt, S.D. (1994). The commitment-trust theory of relationship marketing. Journal of Marketing, 58(3), 20-38.

Newman, J.W. \& Werbel, R.A. (1973). Multivariate analysis of brand loyalty for major household appliances. Journal of Marketing Research, 10, 404-409. Cited in Kabiraj, S., \& Shanmugan, J. (2011). Development of a Conceptual Framework for Brand Loyalty: A Euro-Mediterranean Perspective. Journal of Brand Management, 18(4/5), 285-299. http://dx.doi.org/10.1057/bm.2010.42

Ponsonby-McCabe, S., \& Boyle, E. (2006). Understanding brands as experiential spaces: Axiological implications 
for marketing strategists. Journal of Strategic Marketing, 14(2), 175-189. http://dx.doi.org/10.1080/10427710600662983

Priyadarshi, P. (2011). Employer Brand Image as Predictor of Employee Satisfaction, Affective Commitment \& Turnover. The Indian Journal of Industrial Relations, 46(3), 510-522.

Punniyamoorthy, M., \& Raj, P.M. (2007). An Empirical Model for Brand Loyalty Measurement. Journal of Targeting, Measurement and Analysis for Marketing, 15(4), $222-233$. http://dx.doi.org/10.1057/palgrave.jt.5750044

Rosenbaum-Elliot, R., Percy, L., \& Pervan, S. (2011). Strategic Brand Management (2 ${ }^{\text {nd }}$ ed.). Oxford, Oxford University Press.

Sahin, A., Zehir, C., \& Kitapçı, H. (2011). The Effects of Brand Experiences, Trust and Satisfaction on Building Brand Loyalty: An Empirical Research On Global Brands. Procedia Social and Behavioural Sciences, 24, 1288-1301. http://dx.doi.org/10.1016/j.sbspro.2011.09.143

Sargeant, A., \& Lee, S. (2004). Trust and relationship commitment in the United Kingdom voluntary sector: Determinants of donor behaviour. Psychology and Marketing, 21(8), 613-635. http://dx.doi.org/10.1002/mar.20021

Saunders, M., Lewis, P., \& Thornhill, A. (2012). Research Methods for Business Students (6 ${ }^{\text {th }}$ ed.). Harlow, Pearson Education Ltd.

Srivastava, P., \& Owens, D.L. (2010). Personality Traits and Their Effect on Brand Commitment: An Empirical Investigation. Marketing Management Journal, 20(2), 15-27.

SSB. (2012). 5 Folkemengd, etter kjønn, alder og kommune. 1. januar 2012. Oslo. Retrieved $23^{\text {rd }}$ July 2013 , from http:/www.ssb.no/a/kortnavn/folkemengde/arkiv/tab-2012-02-23-05.html

Sung, Y., \& Campbell, K.W. (2009). Brand commitment in consumer-brand relationships: An investment model approach. Journal of Brand Management, 17(2), 97-113. http://dx.doi.org/10.1057/palgrave.bm.2550119

Sutikno, B. (2011). Does Consumers' Brand Identification Matter: The Mediating Roles of Brand Loyalty. The International Journal of Interdisciplinary Social Sciences, 6(3), 1833-1882.

Traylor, M. B. (1984). Ego involvement and brand commitment: not necessarily the same. Journal of Consumer Marketing, 1(2), 75-79.

Wang, Y., Lo, H. P., Chi, R., \& Yang, Y. (2004). An integrated framework for customer value and customer-relationship- management performance: a customer-based perspective from China. Managing Service Quality, 14(2/3), 169-182.

Wel, C.A..B.C., Alam, S.S., \& Nor, S.M. (2011). Factors Affecting Brand Loyalty: An Empirical Study in Malaysia. Australian Journal of Basic and Applied Sciences, 5(12), 777-783.

Yoo, B., \& Donthu, N. (2001). Developing and validating a multidimensional consumer-based brand equity scale. Journal of Business Research, 52(1), 1-14. http://dx.doi.org/10.1016/S0148-2963(99)00098-3

Zarantonello, L., \& Schmitt, B.H. (2010). Using the brand experience scale to profile consumers and predict consumer behaviour. Brand Management, 17(7), 532-540. http://dx.doi.org/10.1057/bm.2010.4 